\title{
TIME-FREQUENCY NEXUS BETWEEN THE EASTERN EUROPEAN AND THE DEVELOPED STOCK MARKETS - THE CASE OF VISEGRAD GROUP
}

\author{
Dejan Živkov* \\ Novi Sad School of Business \\ Novi Sad, Republic of Serbia \\ Emilija Mihajlović \\ Novi Sad School of Business \\ Novi Sad, Republic of Serbia \\ Kristina Kostić \\ Novi Sad School of Business \\ Novi Sad, Republic of Serbia
}

\begin{abstract}
This paper determines the level of interrelationship between the four stock markets of Visegrad group and the two major developed stock markets (Germany and the US). We endeavor to stipulate the dynamic connection via time domain as well as frequency domain, and for that purposs we apply wavelet coherence methodology. The results indicate that dark-red areas prevail around the World financial crisis and the European sovereign debt crisis, and they exist even at the high frequency areas (4 days) at DAX-PX and DAX-WIG, and somewhat DAX-BUX pairs. It is an indication of strong links between Visegrad group and DAX index, while the ties with the American index are slightly weaker. Slovakian SAX index has the widest areas of low correlation, whereas the presence of contagion cannot be found. This finding suggests that the Slovakian SAX index has the least synchronized movements with the two major stock indices, and thus can be used for diversification purposes in portfolios with DAX and $S \& P 500$.
\end{abstract}

Key words: stock markets, Visegrad group, wavelet coherency, contagion and interdependence

JEL classification: C15, C69, G15

\footnotetext{
*dejanzivkov@gmail.com
} 


\title{
VREMENSKO-FREKVENTNA VEZA IZMEĐU ISTOČNOEVROPSKIH I RAZVIJENIH TRŽIŠTA AKCIJA - SLUČAJ VIŠEGRADSKE GRUPE
}

\begin{abstract}
Apstrakt: Ovaj rad utvrđuje nivo međusobne veze između četiri tržišta akcija višegradske grupe $i$ dva razvijena tržišta akcija (Nemačke i Amerike). Nastojimo da utvrdimo dinamičku vezu preko vremenskog domena, kao i domena frekvencije, $i$ za te svrhe koristimo metodu wavelet koherencije. Rezultati ukazuju da tamnocrvena polja preovlađuju oko Svetske finansijske krize i Evropske krize suverenog duga, i one postoje čak $i$ na poljima visoke frekvencije (4 dana) u parovima DAX-PX,DAX-WIG, i donekle $D A X-B U X$. To ukazuje na snažne veze između Višegradske grupe i DAX indeksa, dok su veze sa američkim indeksom nešto slabije. Slovački SAX indeks ima najšire polje niske korelacije, dok prisustvo ,zaraze“ ne može da bude pronađeno. Ovaj nalaz sugeriše da slovački SAX indeks ima najmanje sinhronizovano kretanje sa dva velika tržišna indeksa, i stoga može biti upotrebljen za potrebe diverzifikacije u portfolijima sa DAX $i$ $S \& P 500$ indeksima.
\end{abstract}

Ključne reči: tržište akcija, Višegradska grupa, wavelet koherencija, ,zaraza“ $i$ međuzavisnost

\section{INTRODUCTION}

The world economy of today is a dynamic network with multiple interlinks where global investors get more efficient in transferring their investments from one market to other markets. In such environment, Central and Eastern European $(C E E)$ stock markets have become interesting for the international investors in the last fifteen year for several reasons. Firstly, these fast-growing markets offered relatively high yields on investments and served as promising opportunity for the regional portfolio diversification. Secondly, as they are becoming more and more integrated into developed markets, these markets are susceptible to the shocks and fluctuations that originate in the developed stock markets. Thus, increased co-movement between stock markets can reduce the efforts of creating an efficient internationally diversified portfolio (see e.g. Mensi, Hammoudeh, Reboredo and Nguyen, 2014; Zhang, Li and Yu, 2013). Thirdly, stock markets can be regulated via the analysis of the linkage between CEE stock markets and developed markets by policy makers, as Boubaker and Jouini (2014) contended. Therefore, analyzing dynamic interdependence between developed and CEE stock markets can have multiple benefits for various market participants, policy makers and academic scholars. However, as Syllignakis and Kouretas (2011) asserted, evidence on the nexus between these markets remains relatively limited, so further insight might be useful. 
In order to stipulate the nature of the relationship between various financial markets and their level of co-movement and spillovers, the existing papers have used, inter alia, the following methods. For instance, Gilmore and McManus (2002) applied Vector Autoregressive (VAR), models; cointegration analysis was used by Patev, Kanaryan and Lyroudi (2006); GARCH models were the method of choice by Cha and Jithendranathan (2009), Égert and Kočenda (2010) and Mazin, Hatemi and Irandoust (2010); regime switching models were utilized by Moore and Wang (2007), Liu, Margaritis and Wang (2012) and Bejaoui and Karaa (2016). However, most researchers that have studied the dynamic connection between various financial markets, observed this phenomenon only via time dimension, neglecting the frequency dimension characteristics that exist in financial time series. Conlon and Cotter (2012) explained that sample reduction problem emerges when researchers try to match the frequency of data with the different time horizons, hence the multiscale analysis in economy has been little studied in general. However, this issue could be very important as Huang (2011) asserted, because the market nexus could differ across time scales and the features in frequency dimension can help to better understand the complex patterns that exist between the two financial variables.

According to the above, this paper strives to understand the dynamic interconnection that exist between stock markets of Visegrad group (the Czech Republic, Poland, Hungary and Slovakia) and stock markets of two major developed economies - Germany and the USA. In order to determine the elaborate nexus between these markets, our approach considers the time-domain neus as well as multi-horizon nature of the co-movement. In that manner, following some recent papers such as Dajčman (2013), Aloui and Hkiri (2014) and Reboredo, Rivera-Castro and Ugolini (2017), we utilize a relatively novel approach of wavelet coherence, which is a powerful mathematical tool for a time-frequency representation of a time-series interconnection. Unlike traditional methodologies, this technique can simultaneously capture both time and frequency domain, without shrinking the sample size, i.e. without loss of valuable information. According to Dewandaru, Masih and Masih (2016), this characteristic is particularly useful when we deal with signals which are nonstationary and contain numerous outliers, which are common characteristics in financial data. In addition, by applying the wavelet coherence tool we can assess which driving force determines the mutual nexus between observed stock markets - contagion or fundamental interdependence. Our study is different from most of prior studies, since, to the best of our knowledge, this paper emphasizes the multi-horizon nature of stocks co-movement between the Visegrad group countries and developed economies. 
18 I TIME-FREQUENCY NEXUS BETWEEN THE EASTER EUROPEAN AND THE DEVELOPED STOCK MARKETS - THE CASE OF VISEGRAD GROUP

Besides introduction, the rest of the paper is structured as follows. The second section presents brief literature survey, while the third section explains the utilized wavelet coherence methodology. Dataset and preliminary analysis are contained in fourth section, and empirical results of wavelet coherence are shown in the fifth section. Section six presents summary and offers a conclusion.

\section{BRIEF LITERATURE REVIEW AND RELATED STUDIES}

Many papers explored the nexus between developed and emerging equity markets (see e.g. Marçal, Pereira, Martin and Nakamura, 2011; Kiviaho, Nikkinen, Piljak and Rothovius, 2014; Lehkonen and Heimonen, 2014). Regarding only the Central and Eastern European countries, this section provides a short overview of extant studies that examined the interrelationship between CEE and developed stock markets. For instance, the research paper of Wang and Moore (2008) used DCC-GARCH model to investigate the extent to which the three emerging CEE stock markets (the Czech Republic, Poland and Hungary) have become integrated into the aggregate Eurozone. They found a higher level of the stock market correlation during the various crisis periods and that interrelationship between these markets depends on the existing levels of financial sector development for the Czech Republic and Hungary. In the study of Gilmore, Lucey and McManus (2008), authors investigated the co-integration properties between the German equity market and those of the Czech Republic, Hungary, and Poland. Their results revealed increasing integration of the Czech, Hungarian, and Polish markets with those of Germany and the United Kingdom. Babetskii, Komarek and Komarkova (2007) considered the empirical dimension of financial integration among stock-exchange markets in four new European Union member states (Czech Republic, Hungary, Poland, and Slovakia) in comparison with the euro area. They disclosed that respective stock-markets integration exists on both national and sectoral levels between the Czech Republic, Hungary, Poland, and the euro area.

More recent manuscript of Boubakera and Jouini (2014) investigated the international equity market causal links between CEE countries and developed countries (Western Europe and the United States), applying the pooled mean group $(P M G)$ approach. They found that the impact of developed markets on emerging markets is more important than reverse effect, while the bidirectional impact is higher between emerging and Western European markets than between these emerging markets and the US. Their findings supported the stance that CEE stock markets are closely interlinked with the developed European markets. Demian (2011) utilized a VAR model to stipulate whether co-integration relationships exist in CEE and whether EU accession had an impact on the number of relationships. He found that EU accession, in itself, 
was not a crucial factor in the development of co-integration in the region, but factors such as liberalization of capital flows and foreign direct investment play a bigger role in the nexus development with other markets. In the paper of Horváth and Petrovski (2013), the authors investigated the international stock market co-movements between Western Europe vis-a-vis Central (Czech Republic, Hungary and Poland) and South Eastern Europe (Croatia, Macedonia and Serbia) using multivariate GARCH models. They demonstrated that the level of interlinks is much higher for Central Europe, while the correlation of South Eastern European stock markets with developed markets is non-existent. In addition, they showed that all stock markets fall considerably at the beginning of the world financial crisis, but they did not find that the crisis changed the degree of stock market integration between these groups of countries. Boubaker and Raza (2016) evaluated the dynamic and asymmetric co-movement of six CEE equity markets with the US stock markets using timevarying copulas. The results showed that US-Hungary pair has the greatest interconnection followed by the pairs of US and Poland and US and Czech Republic, implying in this way a higher degree of market integration.

\section{WAVELET COHERENCE AND WAVELET PHASE DIFFERENCE}

Wavelet methodology presents the estimation of the spectral characteristics of a time-series as a function of time, showing how the different periodic components of a particular time-series evolve over time. Following Rua and Nunes (2009), the continuous wavelet transform $W_{x}(u, s)$ is obtained by projecting a specific wavelet $\psi\left(\right.$.) onto the examined time series $x(t) \in L^{2}(\mathbb{R})$ by the following expression:

$$
W_{x}(u, s)=\int_{-\infty}^{\infty} x(t) \frac{1}{\sqrt{s}} \bar{\psi} \overline{\left(\frac{t-u}{s}\right)} d t
$$

where $u$ represents the position of the wavelet in the time domain while $s$ portrays the position in the frequency domain. From equation (1), information on time and frequency can be simultaneously acquired by mapping the original time series into a function of $u$ and $s$ in the wavelet transform.

The concepts of a bivariate framework called wavelet coherency and wavelet phase-difference are natural generalizations of the basic wavelet analysis tools and it determines the time-frequency dependencies between two time-series. Particularly, CWT needs to be applied in order to investigate the interaction between two time-series on how closely $\mathrm{X}$ and $\mathrm{Y}$ are related by a linear transformation (see Rahim and Masih, 2016). According to Vacha and Barunik (2012), the squared wavelet coherence measures the local linear correlation between two stationary time series at each level of the wavelet scale, and it is 
$20 \mid$ TIME-FREQUENCY NEXUS BETWEEN THE EASTER EUROPEAN AND THE DEVELOPED STOCK MARKETS - THE CASE OF VISEGRAD GROUP

equivalent to the squared correlation coefficient in linear regression. Referring to Torrence and Webster (1999), CWT is defined as the squared absolute value of the smoothed cross wavelet spectra normalized by the product of the smoothed individual wavelet power spectra of each selected time series. The cross wavelet transform of two time-series, $\mathrm{x}(\mathrm{t})$ and $\mathrm{y}(\mathrm{t})$, is defined as $W_{x y}(u, s)=W_{x}(u, s) \overline{W_{y}}(u, s)$, wherein $W_{x}$ and $W_{y}$ are the wavelet transforms of $\mathrm{x}$ and $\mathrm{y}$, respectively. The squared wavelet coherence coefficient is given as follows:

$R^{2}(u, s) \frac{\left|s\left(s^{-1} W_{x y}(u, s)\right)\right|^{2}}{S\left(s^{-1}\left|W_{x}(u, s)\right|^{2}\right) S\left(s^{-1}\left|W_{y}(u, s)\right|^{2}\right)}$

where $S($.$) stands for a smoothing operator and s$ is a wavelet scale. The squared wavelet coherence coefficient ranges $0 \leq R^{2}(u, s) \leq 1$, where values near zero point to weak correlation, while values near one indicate strong correlation. CWT is estimated by applying the Monte Carlo simulation methods.

CWT methodology is unable to stipulate whether dependence between two time-series is positive or negative because the wavelet coherence is squared. Thus, we also consider wavelet coherence phase differences, which describes details about the delays in the oscillation (cycles) between the two time-series under study. Following Torrence and Webster, 1999, the wavelet coherence phase difference is defined as follows:

$\phi_{x y}(u, s)=\tan ^{-1}\left(\frac{\Im\left\{s\left(s^{-1} W_{x y}(u, s)\right)\right\}}{\Re\left\{S\left(s^{-1} W_{x y}(u, s)\right)\right\}}\right)$

Phase difference between two series $(\mathrm{x}, \mathrm{y})$ is indicated by arrows on the wavelet coherence plots. As Vacha and Barunik (2012) asserted, right (left) pointing arrows indicate that the time series are in-phase (anti-phase) or are positively (negatively) correlated. If arrows point to the right and up, the second variable is lagging and if they point to the right and down, the second variable is leading. Reversely, if arrows point to the left and up, the second variable is leading and if arrows point to the left and down, the second variable is lagging.

\section{DATASET AND PRELIMINARY ANALYSIS}

Our dataset comprises daily spot closing prices of selected indices - PX (the Czech Republic), WIG (Poland), BUX (Hungary, SAX (Slovakia), DAX (Germany) and S\&P500 (USA). All daily stock prices are transformed into logreturns according to $r_{i, t}=100 \times \log \left(P_{i, t} / P_{i, t-1}\right)$, where $r_{i, t}$ is the stock market return and $P_{i, t}$ is the stock closing price for index $(i)$. The sample covers the period from January 1, 2001 to December 31, 2017 and all data was obtained SCHOOL OF BUSINESS, 1/2019, 15-31 
from DataStream. Regarding the unavailability of some data because of national holidays and non-working days in selected stock markets, the daily dates are synchronized between two markets according to the existing observations. The concise descriptive statistics accounts for the first four moments, and JarqueBera tests of the selected assets, and their values are summarized in Table 1. It can be seen that all Visegrad group countries except the Czech Republic have higher average stock returns in comparison with the developed markets, and it particularly applies for WIG and BUX indices. Standard deviation measure suggests that average level of risk is relatively equable among all selected stock markets. Higher returns and similar level of risk with developed stock markets, make CEE stock indices suitable assets in portfolios with DAX and S\&P500 indices. SAX index has the highest skewness and kurtosis in comparison to all other indices, which is an indication of the fat tail presence and also that the left side of the probability density function is longer than the right side. JB test shows that the null hypothesis of normal distribution is rejected in all cases.

Table 1

Descriptive statistics of selected assets

\begin{tabular}{l|ccccc}
\hline & Mean & St. dev. & Skewness & Kurtosis & JB \\
\hline $\boldsymbol{P X}$ & 0.012 & 1.523 & -0.116 & 6.966 & 0.000 \\
$\boldsymbol{W I G}$ & 0.027 & 1.239 & -0.347 & 6.235 & 0.000 \\
$\boldsymbol{B} \boldsymbol{U} \boldsymbol{X}$ & 0.036 & 1.526 & -0.097 & 9.657 & 0.000 \\
$\boldsymbol{S A X}$ & 0.032 & 1.196 & -0.775 & 19.438 & 0.000 \\
$\boldsymbol{D A X}$ & 0.011 & 1.534 & -0.036 & 7.293 & 0.000 \\
$\boldsymbol{S \& P 5 0 0}$ & 0.014 & 1.236 & -0.190 & 11.944 & 0.000 \\
\hline
\end{tabular}

Note. Calculated by the authors (JB stands for $\mathrm{p}$-value of Jarque-Bera coefficients of normality).

In order to further investigate raw data properties at various frequency scales, we compute continuous wavelet power spectrum of a single time series and the plots are presented at Figure 1. According to Yang, Cai, Zhang and Hamori (2016) red areas of the continuous power spectra indicate to strong volatility, while yellow, green and blue surfaces represent weaker variability of a single time series. It is obvious that a common pattern emerges across all plots. High volatility exists during the whole sample period at lower scales (2 and 4 days) in all indices, while at the higher scales it slowly fades away. However, during World financial crisis (WFC) around 2009-2010 strong variation also persists at lower frequencies (16 days), which is an indication that the global financial crisis had tremendous impact on both developed stock markets and Eastern 
22 | TIME-FREQUENCY NEXUS BETWEEN THE EASTER EUROPEAN AND THE DEVELOPED STOCK MARKETS - THE CASE OF VISEGRAD GROUP

European emerging stock markets. In addition, it can be seen that developed stock markets suffered stronger volatility impact during the Iraqi war around 2003 in comparison to all CEE markets, which perseveres up to fourth scale (16 days).
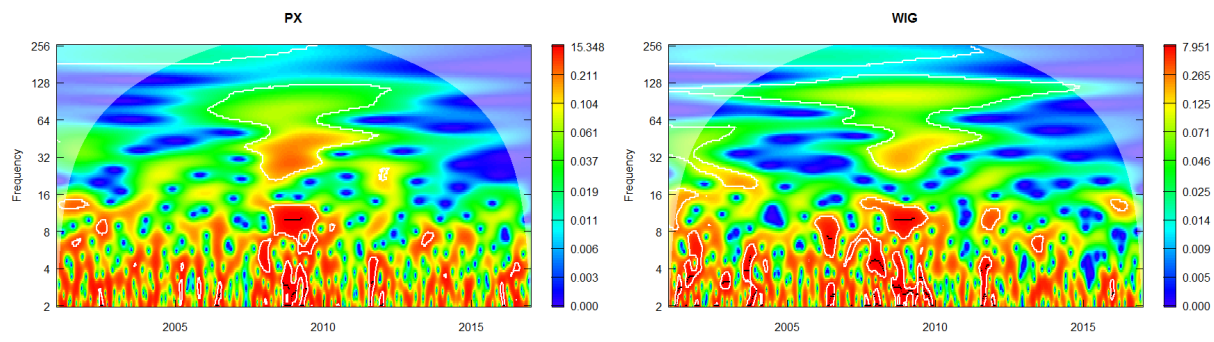

BuX
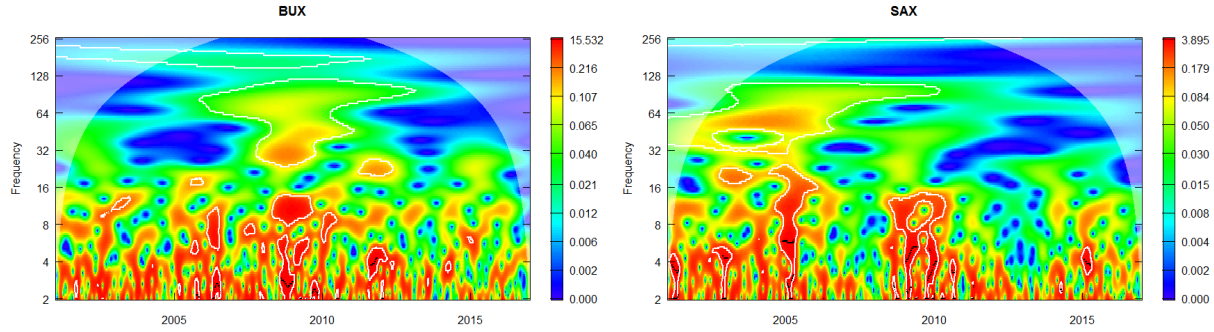

DAX
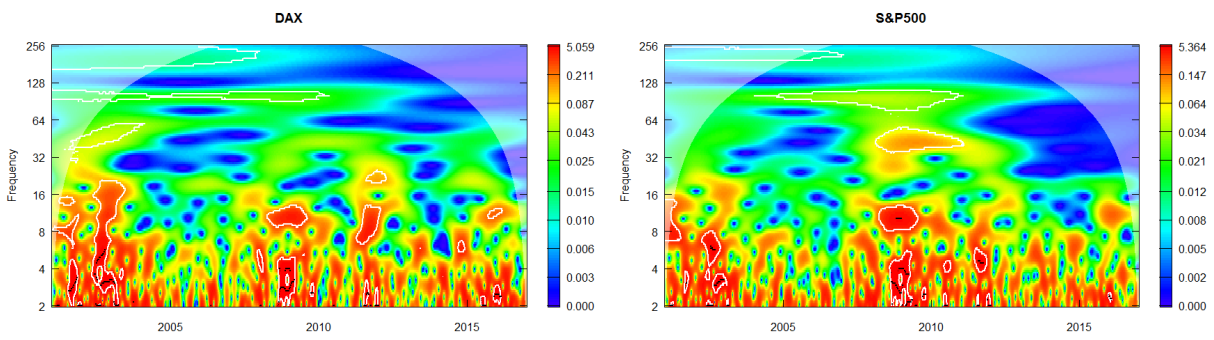

Figure 1. Continuous wavelet power spectrum of a single time series

Note. Calculated by the authors. This figure plots the CWT of the selected indices, based on Morlet's wavelet at daily frequency.

Table 2 presents the Pearson's unconditional correlation results, which is a preliminary indication of how strong mutual nexus between developed stock markets and Visegrad group is. According to these results, the strongest link exists between the Polish and German stock indices, while the connection between the Czech and German index follows. PX, WIG and BUX indices have lower Pearson's correlation with S\&P500, which is expected taking into account smaller trading links with US and greater geographical distance. Unlike 
all other Visegrad markets, Slovakian index shows weak ties with both German and the US stock market. Linear Pearson's correlation coefficients have very limited explanation potential, since they portray average static correlation at one day frequency. Thus, in the following section, we augment our analysis with the wavelet coherence methodology, which is capable to calculate the strength of the interrelationship between developed and CEE stock markets across time and various frequency scales.

Table 2

Pearson's unconditional correlation

\begin{tabular}{lcccc}
\hline & PX & WIG & BUX & SAX \\
\hline $\boldsymbol{D A X}$ & $0.503^{*}$ & $0.529^{*}$ & $0.486^{*}$ & 0.014 \\
$\boldsymbol{S} \& \boldsymbol{P 5 0 0}$ & $0.332^{*}$ & $0.365^{*}$ & $0.348^{*}$ & $0.030^{* * *}$ \\
\hline
\end{tabular}

Note. Calculated by the authors

$*$ and $* * *$ indicate statistical significance at $1 \%$ and $10 \%$ level, respectively.

\section{WELVET COHERENCE - EMPIRICAL FINDINGS}

We apply wavelet coherence in order to decompose the series, and this section contains our findings. Figure 2 contains a wavelet square coherence contour plots between stock indices of two developed markets and four Visegrad group stock indices. Wavelet coherence observes two dimensions - time and frequency domains, whereby the horizontal axis depicts time component, whereas the left vertical axis denotes frequency component, which goes up to scale eight (256 days) that is approximately one year. The strength of the comovement between analyzed group of countries is gauged via color surfaces, were blue color indicates low coherency, while wormer colors point to higher coherency. The color pallet is presented at right $\mathrm{Y}$-axis and it ranges from 0 to 1.

With the help of this methodology, we are able to identify whether observed financial market fluctuations occur mainly due to contagion or fundamentals. Since our study covers relatively long time-span, which is permeated with various crisis events (Iraqi war, World financial crisis, European sovereign debt crisis, the Arab spring, Ukrainian crisis, etc.) it is useful to know how and if these occurrences affected mutual nexus between analyzed stock markets. This is important information for market participants because if cross market linkages happen due to a contagion, they most likely will disappear after a few days. On the other hand, increased co-movements which are caused by fundamental variables are likely to continue for a longer time. Jung and Maderitsch (2014) defined interdependence as a state of stable period 
relationships that are driven by fundamentals, which emphasizes real linkage for transmission shocks between two markets in crisis and non-crisis periods. In contrast, Forbes and Rigobon (2002) explained that contagion is a significant increase in cross-market linkages after the occurrence of a shock in one country. Dornbusch, Park and Claessens. (2000) found the two distinctive characteristics between pure and fundamentals-based contagion. They asserted that the former is defined as an excessive transmission of shocks beyond any idiosyncratic disturbances and fundamental linkages, while the letter is transmitted by way of financial market integration and trade linkages. As for the wavelet coherence point of view, Bodart and Candelon (2009) contended that strong wavelet coherence at the higher frequencies tends to be indicated as contagion, whereas strong wavelet coherence at the lower frequencies can be classified as interdependence.

Looking at the higher frequencies (2-8 days) in all wavelet coherency plots, green, light blue and yellow areas dominate throughout whole period. This finding suggests that in a very short period, moderate coherence exists between Visegrad group stock markets and the developed stock markets. This is the expected feature, since usually local and idiosyncratic events prevail in a very short period of time. However, situation differs substantially at fourth time-scale (16 days) and beyond, where red color dominates, which implies that fundamentals define the relationship at midterm and long-term. In addition, it is interesting to notice that dark-red islands with white line can be found in various sizes in all plots, usually at mid-term and long-term frequencies. These areas indicate very high coherency between two markets, i.e. very strong interconnection. As can be seen, dark-red areas dominate around the World financial crisis and the European sovereign debt crisis, and they outreach even the high frequency areas (4 days) at DAX-PX and DAX-WIG plots, and somewhat DAX-BUX plot. These findings indicate that at this period a contagion took place between these markets. Contagion effect is also present in combinations PX, WIG, BUX with S\&P500, but it is less conspicuous.

According to Boyer et al. (2006), contagion can be investor induced through portfolio rebalancing, where it can be described in behavioral finance literature as herding effect. This phenomenon occurs because investors follow other investors, i.e. trade in the same direction over a period of time, which has been characterized by Hirshleifer and Teoh (2003) as "convergence of behaviors". Our findings coincide with the results of Syllignakis and Kouretas (2011), who used DCC-GARCH model and showed that positive dynamic correlations between Czech, Polish and Hungarian index and German index increased substantially during the World financial crisis. 
DAX-PX

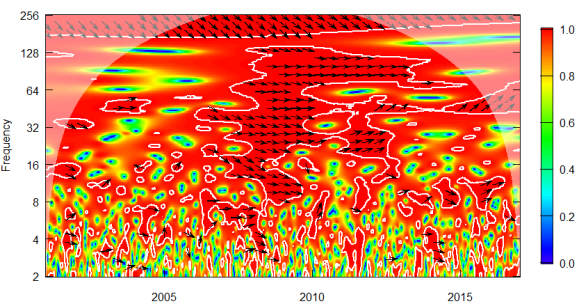

DAX-BUX

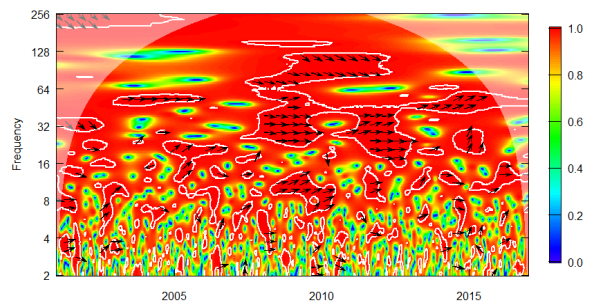

S\&P500-PX

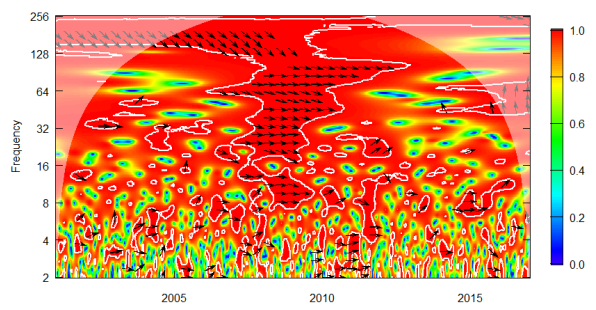

S\&P500-BUX

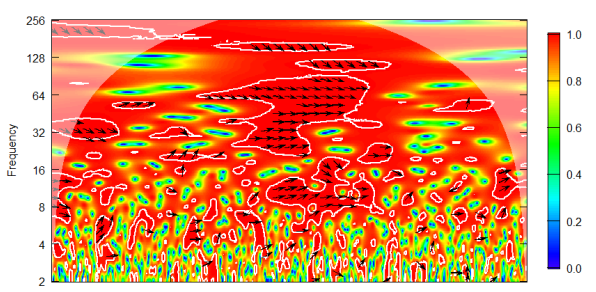

2005

2010

2015

Figure 2. Wavelet square coherence.

Note. Authors' calculations.
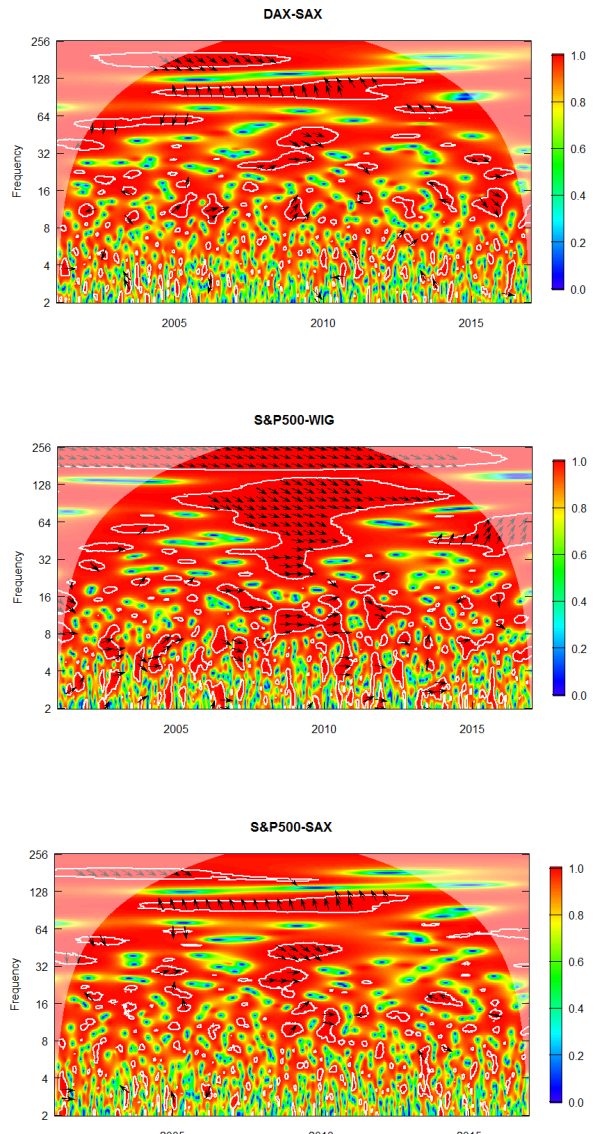

2005

2015 

STOCK MARKETS - THE CASE OF VISEGRAD GROUP

However, our results are more thorough because we can identify in which timescales those high correlations happened and persevered. In addition, at low frequency scales ( 32 days and beyond), dark-red areas are rather a sign of strong interdependence fueled by fundamentals than mere contagion. Analogous to the paper of Syllignakis and Kouretas (2011), we find that the links between Visegrad group and DAX index are stronger in comparison with the ties with the American index. This is expected since Germany developed stronger trading and financial links with these countries, most likely due to shorter geographical distance. Thus, shocks from the German market spilled over faster to the CEE stock markets during the World crisis and their effects are manifested at higher frequencies (lower scales), particularly for the PX and WIG cases.

In addition, Figure 2 shows that dark-red areas can be spotted at very high frequencies (4 days) and even higher (2 days) around 2011 in the S\&P500-PX and S\&P500-WIG plots. This period corresponds with the US debt-ceiling crisis that took place in summer of 2011, when the US Congress debated about the appropriate level of government spending and its effect on the national debt and deficit. According to wavelet coherence plots, this uncertainty that came from the largest world economy had strong impact on the Czech and Polish stock market and somewhat smaller effect on the Hungarian market. However, Hungarian stock market demonstrated very strong linkages with the US stock market between 2008 and 2012 on the eight wavelet scale. Moreover, the darkred island in the S\&P500-BUX plot is the largest around this period in comparison to high coherency areas in all other S\&P500- plots. These results are in accordance with the findings of Boubaker and Raza (2016), who contended that US-Hungary pair exhibits the highest degree of market integration followed by the pairs of US-Poland and US-Czech Republic.

Also, it is interesting to perceive that the Czech index suffered high shock impact from the increased volatility from the German and US stock market around 2015 at level three of the wavelet scale (8 days). As Figure 1 indicates, notably enhanced volatility was present at German and US stock markets around that period. At that time, Ukrainian crisis was at its height, war raged in Syria, but most likely cause for increased volatility in the developed markets was sudden and dramatic oil price drop that apparently spilled over to the Czech stock market. In addition, it is worth noticing that around 2003, i.e. during Iraqi war, small areas of high coherency are present at fourth level of the wavelet scale at the DAX-WIG plot and around the eighth point of the wavelet scale at the DAX-BUX plot. As can be seen at Figure 1, the DAX index reacted more vigorously to Iraqi war than S\&P500 index. Obviously, the part of this volatility was transferred to the Polish and Hungarian stock markets and we recorded it as high wavelet coherency between these markets. Besides, dark arrows of wavelet phase difference in dark-red areas are, in most cases, pointed in the right 
direction at higher as well as lower frequencies, which signifies that these markets were in phase, i.e. positive correlation was present between analyzed stock markets. This indicates that whether the nexus between CEE and developed markets is classified as interdependence or contagion, the forces that mold this relationship act in the same direction.

On the other hand, at DAX-SAX and S\&P500-SAX plots, the presence of contagion cannot be viewed. The SAX case reveals that only small island of dark red can be found around 2008-2009 at mid-term frequency (32 days), which is an indication of low financial integration with the major stock markets. These results are in line with our preliminary Pearson's unconditional correlation and with the study of Savva and Aslanidis (2010). These authors applied smooth transition conditional correlation model and disclosed that between Slovakia and Eurozone exists very low correlation. Syllignakis and Kouretas (2011) also analyzed Slovakia and found that the magnitude of dynamic correlation between the Slovakian and German stock market during the World crisis reached 24\%, while in cases of the Czech, Polish and Hungarian markets it amounted to $75 \%, 65 \%$ and $70 \%$, respectively. Also, during the US sovereign debt crisis in 2011, SAX seemed to be unaffected. Our wavelet coherence findings suggest that Slovakia has the widest surface under the green, yellow and blue areas which points to the conclusion that the Slovakian SAX index has the least compliant movements with the major stock indices. In other words, the SAX index could serve very well as an auxiliary asset in risk-minimizing portfolios with the DAX and S\&P500 indices.

\section{SUMMARY AND CONCLUSION}

This paper tries to gauge the level of interconnection between four stock markets of Visegrad group and two major developed stock markets of Germany and the US. Unlike all other previous studies which dealt with this topic and observed interdependence via time domain only, this paper goes one step further and observes dynamic connection via frequency domain as well. For the research purposes, we used wavelet coherence methodology, which is a powerful mathematical tool for a time-frequency representation of a time-series interconnection. In addition, by applying this research technique, we are able to distinguish between periods of pure market contagion and fundamental based interdependence.

The results indicate that dark-red areas dominate around the World financial crisis and the European sovereign debt crisis, even at the high frequency areas (4 days) in the DAX-PX and DAX-WIG plots, and somewhat the DAX-BUX plot. It means that links between Visegrad group and the DAX index are stronger in comparison with the ties between Visegrad countries and the 
28 IIME-FREQUENCY NEXUS BETWEEN THE EASTER EUROPEAN AND THE DEVELOPED STOCK MARKETS - THE CASE OF VISEGRAD GROUP

American index. This is an indication that shocks from the German market spilled over faster to the CEE stock markets during the World crisis and that their effects are manifested at higher frequencies (lower scales) as well. On the other hand, our wavelet coherence findings suggest that Slovakia has the widest areas of low correlation, while the presence of contagion cannot be observed. This finding suggests that the Slovakian SAX index has the least synchronized movements with the major world stock indices. In other words, the SAX index could be used efficiently as a hedging instrument in portfolios with the DAX and S\&P500 indices.

We think that our findings of dynamic nexus between the selected markets could benefit policy makers, investors, and all kinds of market practitioners. These results could help global investors to better understand the connection between emerging equity markets and developed ones, enabling them to make better decisions regarding the diversification process of their portfolios based on the sign and magnitude of the causal links between the different stock markets. Furthermore, governments of the analyzed CE countries could use these results to make sound economic decisions and policy proposals to regulate their equity markets, since we have shown that very high coherency exists between the majority of Visegrad group countries and the developed markets, particularly in crisis periods.

\section{REFERENCE}

Aloui, C., \& Hkiri, B. (2014). Co-movements of GCC emerging stock markets: New evidence from wavelet coherence analysis. Economic Modelling, 36, 421-431.

Babetskii, I., Komarek, L., \& Komarkova, Z. (2007). Financial integration of stock markets among new EU member states and the euro area. Finance $a$ uver - Czech Journal of Economics and Finance, 57(7-8), 341-362.

Boubakera, S., \& Jouini, J. (2014). Linkages between emerging and developed equity markets: Empirical evidence in the PMG framework. North American Journal of Economics and Finance, 29, 322-335.

Boubaker, H., \& Raza, S. A. (2016). On the dynamic dependence and asymmetric co-movement between the US and Central and Eastern European transition markets. Physica A: Statistical Mechanics and its Applications, 459, 9-23.

Bejaoui, A., \& Karaa, A. (2016). Revisiting the bull and bear markets notions in the Tunisian stock market: New evidence from multi-state durationdependence Markov-switching models. Economic Modelling, 59, 529545 . 
Bodart, V., \& Candelon, B. (2009). Evidences of interdependence and contagion using a frequency domain framework. Emerging Markets Review, 10(2), 140-150.

Boubaker, S., \& Jouini, J. (2014). Linkages between emerging and developed equity markets: Empirical evidence in the PMG framework. North American Journal of Economics and Finance, 29, 322-335.

Boyer, B., Kumagai, T., \& Yuan, K. (2006). How do crises spread? Evidence from accessible and inaccessible stock indices. Journal of Finance, 61(2), 957-1003.

Cha, H. J., \& Jithendranathan, T. (2009). Time-varying correlations and optimal allocations in emerging market equities for the US investors. International journal for finance and economics, 14(2), 172-187.

Conlon, T., \& Cotter, J. (2012). An empirical analysis of dynamic multiscale hedging using wavelet decomposition. Journal of Futures Markets, 32(3), 272-299.

Dajčman, S. (2013). Interdependence between some major European stock markets - A wavelet led/lag analysis. Prague economic papers, 22(1), 28-49.

Demian, C. V. (2011). Cointegration in Central and East European markets in light of EU accession. Journal of International Financial Markets, Institutions and Money, 21(1), 144-155.

Dewandaru, G., Masih, R., \& Masih, A. M. M. (2016). Contagion and interdependence across Asia-Pacific equity markets: An analysis based on multi-horizon discrete and continuous wavelet transformations. International Review of Economics and Finance, 43, 363-377.

Dornbusch, R., Park, Y. C., \& Claessens, S. (2000). Contagion: understanding how it spreads. World Bank Research Observer, 15(2), 177-197.

Égert, B., \& Kočenda, E. (2010). Time-varying Synchronization of European Stock Markets. Empirical Economics, 40(2), 393-407.

Forbes, K. J., \& Rigobon, R. (2002). No contagion, only interdependence: measuring stock market comovements. Journal of Finance, 57(5), 22232261.

Gilmore, G. C., \& McManus, G. M. (2002). International Portfolio Diversification: US and Central European Equity Markets. Emerging Markets Review, 3(1), 69-83. 
$30 \mid$ TIME-FREQUENCY NEXUS BETWEEN THE EASTER EUROPEAN AND THE DEVELOPED STOCK MARKETS - THE CASE OF VISEGRAD GROUP

Gilmore, C., Lucey, B., \& McManus, G. (2008). The dynamics of Central European equity market integration. Quarterly Review of Economics and Finance, 48(3), 605-622.

Hirshleifer, D., \& Teoh, S. H. (2003). Herd behaviour and cascading in capital markets: A review and synthesis. European Financial Management, 9(1), $25-66$.

Horváth, R., \& Petrovski, D. (2013). International stock market integration: Central and South Eastern Europe compared. Economic Systems, 37(1), 81-91.

Huang, S. C. (2011). Wavelet-based multi-resolution GARCH model for financial spillover effects, Mathematics and computers in simulation, 81(11), 2529-2539.

Jung, R. C., \& Maderitsch, R. (2014). Structural breaks in volatility spillovers between international financial markets: contagion or mere interdependence? Journal of Banking and finance, 47, 331-342.

Kiviaho, J., Nikkinen, J., Piljak, V., \& Rothovius, T. (2014). The co-movement dynamics of European frontier stock markets. European Financial Management, 20(3), 574-595.

Lehkonen, H., \& Heimonen, K. (2014). Timescale-dependent stock market comovement: BRICs vs. developed markets. Journal of Empirical Finance 28, 90-103.

Liu, X., Margaritis, D., \& Wang, P. (2012). Stock market volatility and equity returns: Evidence from a two-state Markov-switching model with regressors. Journal of Empirical Finance, 19(4), 483-496.

Marçal, E. F., Pereira, P. L. V., Martin, D., \& Nakamura, W. (2011) Evaluation of contagion or interdependence in the financial crises of Asia and Latin America, considering the macroeconomic fundamentals. Applied Economics, 43, 2364-2379.

Mazin, A. M. A. J., Hatemi J. A., \& Irandoust, M. (2010). Modeling TimeVarying Volatility and Expected Returns: Evidence from the GCC and MENA Regions. Emerging markets Finance and Trade, 46(5), 39-47.

Mensi, W., Hammoudeh, S., Reboredo, J. C., \& Nguyen, D. K. (2014). Do global factors impact BRICS stock markets? A quantile regression approach. Emerging Markets Review, 19, 1-17.

Moore, T., \& Wang, P. (2007). Volatility in stock returns for new EU member states: Markov regime switching model. International Review of Financial Analysis, 16(3), 282-292. 
Patev, P, Kanaryan, N., \& Lyroudi, K. (2006). Stock Market Crises and Portfolio Diversification in Central and Eastern Europe. Managerial Finance, 32(5), 415-432.

Rahim, A. M., \& Masih, A. M. M. (2016). Portfolio diversification benefits of Islamic investors with their major trading partners: Evidence from Malaysia based on MGARCH-DCC and wavelet approaches. Economic Modelling, 54, 425-438.

Reboredo, J. C., Rivera-Castro, M. A., \& Ugolini, A. (2017). Wavelet-based test of co-movement and causality between oil and renewable energy stock prices. Energy Economics, 61, 241-252.

Rua, A., \& Nunes, L. C. (2009). International co-movement of stock market returns: a wavelet analysis. Journal of Empirical Finance, 16(4), 632639.

Savva, C. S., \& Aslanidis, N. (2010). Stock market integration between new EU member states and the Euro-zone. Empirical Economy, 39(2), 337-351.

Syllignakis, M. N., \& Kouretas, G. P. (2011). Dynamic correlation analysis of financial contagion: Evidence from the Central and Eastern European markets. International Review of Economics and Finance, 20(4), 717732 .

Torrence, C., \& Webster, P. J. (1999). Interdecadal changes in the ENSOmonsoon system. Journal of Climate, 12(8), 2679-2690.

Vacha, L., \& Barunik, J. (2012). Co-movement of energy commodities revisited: Evidence from wavelet coherence analysis. Energy Economics, 34(1), 241-247.

Wang, P., \& Moore, T. (2008). Stock market integration for the transition economies: time-varying conditional correlation approach. Manchester School. 76(1), 116-133.

Yang, L., Cai, X. J., Zhang, H., \& Hamori, S. (2016). Interdependence of foreign exchange markets: A wavelet coherence analysis. Economic Modelling, 55, 6-14.

Zhang, B., Li, X., \& Yu, H. (2013). Has recent financial crisis changed permanently the correlations between BRICS and developed stock markets? North American Journal of Economics and Finance, 26, 725738 .

Delivered: 22.06.2019. Accepted: 28.11.2019. 